\title{
Fertilization: a sperm's journey to and interaction with the oocyte
}

\author{
Masahito Ikawa, ${ }^{1}$ Naokazu Inoue, ${ }^{1}$ Adam M. Benham,,1,2 and Masaru Okabe1 \\ ${ }^{1}$ Research Institute for Microbial Diseases, Osaka University, Osaka, Japan. ${ }^{2}$ School of Biological and Biomedical Sciences, \\ Durham University, United Kingdom.
}

\begin{abstract}
Mammalian fertilization comprises sperm migration through the female reproductive tract, biochemical and morphological changes to sperm, and sperm-egg interaction in the oviduct. Recent gene knockout approaches in mice have revealed that many factors previously considered important for fertilization are largely dispensable, or if they are essential, they have an unexpected function. These results indicate that what has been observed in in vitro fertilization (IVF) differs significantly from what occurs during "physiological" fertilization. This Review focuses on the advantages of studying fertilization using gene-manipulated animals and highlights an emerging molecular mechanism of mammalian fertilization.
\end{abstract}

\section{Introduction}

In the early 1950s, Min Chueh Chang and Colin Russell Austin independently found that mammalian sperm must spend some time in the female reproductive tract before they acquire the ability to fertilize eggs $(1,2)$. The phenomenon underlying the acquisition of fertilization capability is called sperm capacitation (3), and the discovery of Chang and Austin made it possible to perform mammalian fertilization in vitro by mixing capacitated sperm with ovulated eggs, a procedure used by in vitro fertilization (IVF) clinics today (4) (Figure 1). This simplified in vitro experimental system (5) also allowed researchers to intensively study the mechanism of fertilization. Indeed, using this system together with biochemical approaches, such as competitive binding of antibodies and ligands that interact with sperm, eggs, and their surroundings, various factors were reported to be important for mammalian fertilization.

The development of gene-knockout technology $(6,7)$ has allowed researchers to test in vivo the findings from IVF studies. Numerous factors considered to be key molecules have been examined for their importance during fertilization (Tables 1 and 2). Surprisingly, these experiments revealed that many of the sperm factors thought to be important for fertilization, including the acrosomal protease acrosin (Acr) (8), the zona pellucida (ZP) binding protein $\beta$-1,4-galactosyltransferase 1 (B4galt1) $(9,10)$, and the egg fusion protein fertilin (a heterodimer that consists of two subunits, a disintegrin and metallopeptidase domain $1 \mathrm{~b}$ [Adam1b] and Adam2) (11), were not essential. It can be argued that in vivo, compensatory mechanisms supplant the function of the gene targeted in a knockout mouse. However, these factors were identified as important for fertilization in studies using antibodies that blocked IVF by targeting a single epitope of these factors, and no compensatory mechanisms were detected. Although the likelihood is low that compensatory mechanisms are revealed in gene-knockout mice, it can still be argued that in knockout animals upregulation of unknown, functionally related molecules could take place. Despite these arguments, the view that genes essential for mammalian fertilization do exist has been confirmed by the discovery of proteins whose gene disruptions prevent fertility both in vitro and in vivo (e.g., cation channel, sperm associated 1 [Catsper1], ref. 12, and

Conflict of interest: The authors have declared that no conflict of interest exists. Citation for this article: J Clin Invest. 2010;120(4):984-994. doi:10.1172/JCI41585. izumo sperm-egg fusion 1 [Izumo1], ref. 13). An additional benefit of gene-knockout studies is that they reveal factors that would never have emerged as essential for fertilization from IVF experiments (e.g., angiotensin-converting enzyme [Ace], ref. 14; calmegin [Clgn], ref. 15; and Cd9, refs. 16-18). In this Review, we discuss the current understanding of the mechanism of mammalian fertilization, which has been defined mainly through in vivo analysis of various gene-manipulated animals.

\section{Sperm migration in the female reproductive tract}

Capacitation is the process by which sperm become competent to fertilize an egg (Figure 1). Capacitation takes place after ejaculation, in the female reproductive tract, and is required only by mammalian sperm. Cholesterol is particularly abundant in seminal plasma (19) and has an inhibitory effect on sperm capacitation. During capacitation, cholesterol and other sterols are removed from the sperm surface, and non-covalently attached glycoproteins acquired in the epididymis are released from the sperm surface (20). Together, these modifications create a more fluid membrane environment, making the sperm competent for subsequent fertilization cues.

There are many papers demonstrating the importance of protein phosphorylation, particularly tyrosine phosphorylation, and calcium ion influx for capacitation. These signaling events may also be important for the release of putative "decapacitation factor(s)" from sperm (21). In the IVF clinic, sperm are prepared by the "swim up" method and/or by Percoll density gradient centrifugation to ensure that the sperm are free from seminal plasma, which is believed to contain decapacitation factor(s). Since individual sperm change their biochemical status after collection and incubation and there is no good method to separate them, it is inevitable that in the laboratory, mixed populations of millions of gametes are analyzed at different stages of capacitation and/or the acrosome reaction. It is important to be aware that the global biochemical status of many unsuccessful sperm may not necessarily reflect the molecular events that occur in the one successful sperm that navigates the oviduct and penetrates the $\mathrm{ZP}$, the transparent glycoprotein extracellular matrix that surrounds the egg (Figure 1).

Mammalian sperm have to travel a long distance through the female reproductive tract to the oviduct, in which fertilization takes place. To accomplish the journey to the egg, sperm are 


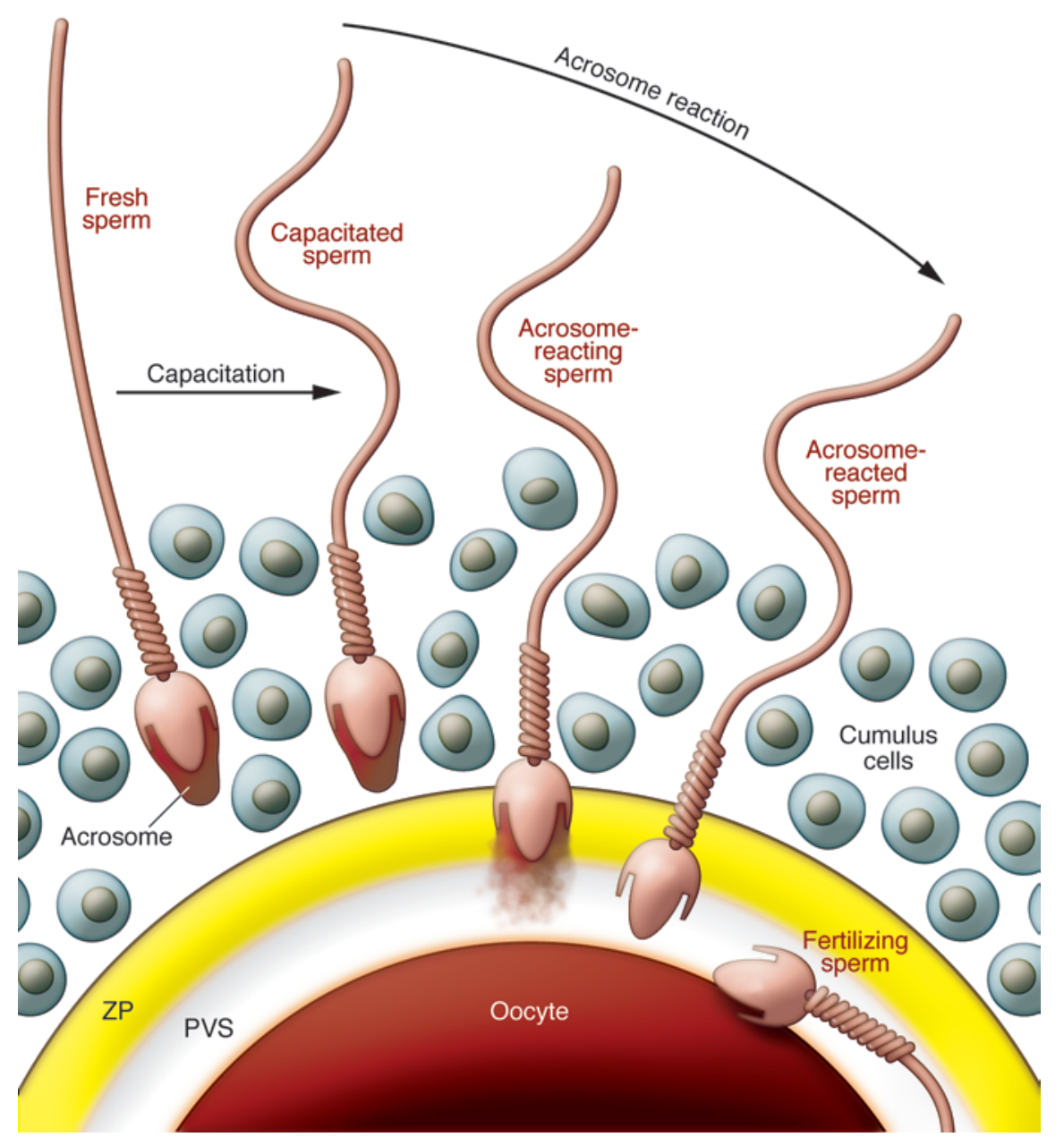

\section{Figure 1}

Mechanism of sperm-egg interaction. Over the nucleus of each mammalian sperm is a membranous sac known as the acrosome, which is filled with many kinds of hydrolytic enzymes. In the female reproductive tract or in an IVF medium, sperm undergo capacitation, which permits the acrosome reaction. Near the eggs, probably stimulated by the cumulus cells and the ZP, sperm release their acrosomal contents by exocytosis and penetrate the ZP. Only acrosome-reacted sperm fuse with eggs, but their competency for fusion does not last long. Cumulus cells are packed together by hyaluronic acid at ovulation and become diffuse during fertilization. PVS, perivitelline space. equipped to overcome various obstacles that lie ahead, such as navigating the uterotubal junction (UTJ) and penetrating the egg extracellular matrices. For example, the cysteine-rich cationic polypeptide defensin $\beta 126$ (DEFB126) has been suggested to coat sperm, and its overall negative charge facilitates sperm attachment to the oviduct epithelium, promoting penetration of the cervical mucus (22). While the function of DEFB126, and other related epididymis-specific defensins, remains to be fully tested in knockout animals, it seems that proteins secreted from male accessory glands regulate sperm migration.

The oviduct is comprised of three major segments: the UTJ, the isthmus, and the ampulla (Figure 2). These structures seem to play distinct roles in ensuring successful fertilization. The UTJ connects the uterus and oviduct by intersecting the distal part of the oviduct. Several lines of evidence obtained from knockout mice suggest that sperm migration through the oviduct is biologically regulated. The sperm from male mice lacking one of the molecules Clgn, Ace, Adam1a, Adam2, or Adam3 are motile but not able to pass through the UTJ (23-27). For Ace, it is the testicular isoform of the protein, which is transcribed from testis-specific promoters in intron 12, that is required for fertility. Adam1a, Adam2, and Adam3 are all glycoproteins with EGF-like and peptidase M12B domains. Clgn is a testis-specific homolog of the ER-resident lectin-like chaperone calnexin. Proteomic analysis of sperm from the mutant mouse lines revealed that the sperm surface protein
Adam 3 is commonly absent or dislocated into detergent-rich membrane domains in all five lines of mutant mice (28). Initially, Adam $3^{-/-}$mice were reported to have no defect in sperm migration (29), but using fluorescent protein-tagged transgenic sperm and live imaging technology (Figure 2), a defect in the oviductal migration of Adam3 $3^{--}$sperm was revealed (27). Adam3 is now considered to be the most important factor in sperm migration in the mouse. The precise mechanism of how Adam 3 facilitates the passage of sperm through the UTJ is unknown. The relationship between the five molecules that cause the disappearance of Adam 3 from sperm will be discussed later in the section on sperm-ZP binding.

After passing through the UTJ, sperm are held on the surface of mucosal folds in the isthmus and remain there until the time of ovulation draws near. In cows, binder of sperm protein (BSP) on the sperm surface and annexin family proteins on the oviduct epithelial surface have been suggested to play important roles in sperm storage in the isthmus $(30,31)$. BSPs are fibronectin type II domain-containing proteins released from the male seminal vesicles (a pair of simple tubular glands that release their contents into the vas deferens), and include PDC109 (BSPA1/A2), BSPA3, and BSP30K. Recently, BSP homologs were found in the human (BSPH1) and mouse (32). It has also been suggested that the reducing redox environment of the oviduct could promote the release of sperm by facilitating the reduction of cell surface thiols on sperm cell proteins important for sperm-oviduct binding (33). 


\section{Table 1}

Genes related to fertility that have been knocked out in mice (A to 0 )

\begin{tabular}{|c|c|c|c|c|}
\hline Gene & Expected roles & Fecundity & Fertility defects observed in knockout mice & Refs. \\
\hline Ace & Blood pressure control & Male, infertile & $\begin{array}{l}\text { Severely reduced ZP binding and defect } \\
\text { of UTJ migration }\end{array}$ & 24 \\
\hline Acr & ZP binding, ZP penetration & Male, delayed fertility & Delayed acrosome reaction & 8,116 \\
\hline Adam1a & Spermatogenesis & Male, infertile & $\begin{array}{l}\text { Severely reduced ZP binding and defect } \\
\text { in UTJ migration }\end{array}$ & 25 \\
\hline Adam1b & Sperm-egg fusion & Male and female, fertile & None & 11 \\
\hline Adam2 & Sperm-egg fusion & Male, infertile & $\begin{array}{l}\text { Severely reduced ZP binding and defect } \\
\text { in UTJ migration }\end{array}$ & 26 \\
\hline Adam3 & Sperm-egg interaction & Male, infertile & $\begin{array}{c}\text { Severely reduced ZP binding and defect } \\
\text { of UTJ migration }\end{array}$ & 27,29 \\
\hline$A m b p$ & Covalent binding to hyaluronan & Female, subfertile & $\begin{array}{l}\text { Reduced ovulation and fertilization rates } \\
\text { accompanied by absent ZP }\end{array}$ & 51 \\
\hline B4galt1 & ZP binding & Male, fertile & Reduced acrosome reaction in response to $\mathrm{Zp} 3$ & 9 \\
\hline Bmp15 & Cumulus expansion and ovulation & Female, subfertile & Defects in ovulation and the integrity of the COC & 117 \\
\hline C1galt1 & $\begin{array}{l}\text { Synthesis of core-1-derived } \\
\text { 0-glycans }\end{array}$ & Male and female, fertile & None & 96 \\
\hline Catsper1 & Sperm capacitation & Male, infertile & $\begin{array}{l}\text { Severely decreased sperm motility and lack } \\
\text { of calcium ion influx }\end{array}$ & 40 \\
\hline$C d 9$ & $\begin{array}{l}\text { Participation in migration and } \\
\text { adhesion in many cell types }\end{array}$ & Female, infertile & Severely reduced sperm-egg fusion & $16-18$ \\
\hline $\mathrm{Cd} 46$ & Sperm-egg interaction & Male, accelerated fertility & Increased acrosome reaction & 118 \\
\hline Cd81 & $\begin{array}{l}\text { Participation in migration and } \\
\text { adhesion in many cell types }\end{array}$ & $\begin{array}{l}\text { Female, severely } \\
\text { reduced fertility }\end{array}$ & Severely reduced sperm-egg fusion & 119 \\
\hline Clgn & Spermatogenesis & Male, infertile & $\begin{array}{l}\text { Severely reduced ZP binding and defect } \\
\text { in UTJ migration }\end{array}$ & 15 \\
\hline Cplx1 & $\begin{array}{l}\text { Binding to the SNARE complex and } \\
\text { regulation of neuronal exocytosis }\end{array}$ & $\begin{array}{l}\text { Male and female, } \\
\text { fertile }\end{array}$ & Reduced acrosome reaction in soluble ZP & 79 \\
\hline Crisp1 & Sperm-egg interaction & Male and female, fertile & Reduced sperm-egg fusion & 120 \\
\hline Defb22A & Microbicidal and cytotoxic peptides & Not examined & Not examined & 22 \\
\hline$D k k / 1$ & Placental development & Male and female, fertile & Severely reduced ZP binding in vitro & 121 \\
\hline Gdf9 & Cumulus expansion and ovulation & Female, subfertile & Defects in ovulation and the integrity of the COC & 122 \\
\hline Hyal5 & Penetration through the cumulus layer & Male and female, fertile & None & 61 \\
\hline Inpp5b & Hydrolyzation of lipid substrates & Male, subfertile & $\begin{array}{l}\text { Severely reduced sperm motility and } \\
\text { defect in Adam2 processing }\end{array}$ & 123 \\
\hline Itga6 & Sperm-egg interaction & Not examined & Normal sperm-egg fusion & 113 \\
\hline $\operatorname{ltg} b 1$ & Sperm-egg interaction & Not examined & Normal sperm-egg fusion & 113 \\
\hline Izumo1 & Sperm-egg fusion & Male, infertile & Failed sperm-egg fusion & 13 \\
\hline Mfge8 & ZP binding & Male and female, fertile & Reduced ZP binding in vitro & 124 \\
\hline Mgat1 & $\begin{array}{l}\text { Synthesis of complex and } \\
\text { hybrid N-glycans }\end{array}$ & Male and female, fertile & Thinner ZP, but eggs fertilized & 95 \\
\hline Napa & Membrane fusion and exocytosis & Male, infertile & Reduced acrosome reaction & 77 \\
\hline
\end{tabular}

ADefb22 (defensin $\beta$ 22) is a mouse homolog of DEFB126. Bmp15, bone morphogenetic protein 15; Crisp1, cysteine-rich secretory protein 1; Dkkl1, dickkopf-like 1; Gdf9, growth differentiation factor 9; Inpp5b, inositol polyphosphate-5-phosphatase B; Itga6, integrin $\alpha_{6}$; Itgb1, integrin $\beta_{1}$; Mfge8, milk fat globule-EGF factor 8 protein.

During sperm storage, the isthmic epithelium creates a microenvironment that delays capacitation and stabilizes sperm for a period of approximately 24 hours, at least in humans $(34,35)$. When ovulation draws near, unknown female factors trigger the sperm to leave the reservoir and move up to the ampulla. Release of sperm from the isthmic epithelium is reported to depend mainly on sperm changes that are associated with capacitation. For example, bull sperm are reported to shed their BSPs and lose their oviduct epithelium-binding ability (36). Hyperactivated sperm movement and asymmetrical beating of the sperm flagellum occurs after capacitation and is thought to assist sperm escaping from the oviduct epithelium (37). The importance of hyperactivated sperm movement in release from the isthmic epithelium is supported by a report that
Catsper1 $1^{-/}$sperm are unable to detach from oviduct epithelium (38). A functional CATSPER channel has been reported to control calcium entry, which stimulates the hyperactivated state $(12,39,40)$. Of clinical interest, human male infertility caused by mutations in the gene encoding CATSPER1 was reported recently (41).

The gradual release of sperm from the isthmus helps to reduce the number of sperm available at the point of fertilization and avoids polyspermy (fertilization of an egg by more than one sperm), which is fatal for embryonic development (42). Surgical removal of the isthmus in the pig leads to increased numbers of sperm entering the ampulla and polyspermy in about one-third of eggs (43), suggesting that the isthmic portion of the female reproductive tract regulates the number of fertilization-competent sperm that 
Table 2

Genes related to fertility that have been knocked out in mice (P to Z)

\begin{tabular}{|c|c|c|c|c|}
\hline Gene & Expected roles & Fecundity & Fertility defects observed in knockout mice & Refs. \\
\hline Pcsk4 & $\begin{array}{l}\text { Family of calcium-dependent } \\
\text { serine proteinase }\end{array}$ & Male, subfertile & $\begin{array}{l}\text { Reduced capacitation, acrosome reaction, } \\
\text { and egg binding in vitro }\end{array}$ & 125 \\
\hline Pgap1 & $\begin{array}{c}\text { GPI inositoldeacylase that removes } \\
\text { palmitate from inositol }\end{array}$ & Male, infertile & $\begin{array}{l}\text { Severely reduced ZP binding and defect } \\
\text { in UTJ migration }\end{array}$ & 103 \\
\hline Piga & Enzyme involved in GPI anchor biosynthesis & Female, infertile & Failed sperm-egg fusion & 114 \\
\hline Pkdrej & Acrosome reaction & Male and female, fertile & Reduced acrosome reaction in soluble ZP & 126 \\
\hline Plcd4 & $\begin{array}{c}\text { Hydrolyzes } \\
\text { phosphatidylinositol-4,5-bisphosphate }\end{array}$ & Male, subfertile & Severely reduced acrosome reaction in soluble ZP & 71 \\
\hline Press21 & Serine protease family & Male and female, fertile & $\begin{array}{l}\text { Severely reduced ZP binding and ZP-induced } \\
\text { acrosome reaction and sperm-egg fusion in vitro, but } \\
\text { rescued by exposure of the sperm to uterine fluids }\end{array}$ & 106 \\
\hline Ptger2 & Prostaglandin E2 receptor & $\begin{array}{l}\text { Female, severely reduced } \\
\text { fertility }\end{array}$ & $\begin{array}{l}\text { Reduced fertilization and defects } \\
\text { in cumulus expansion }\end{array}$ & 56,127 \\
\hline Ptgs2 & Regulation of prostaglandin synthesis & Female, infertile & $\begin{array}{l}\text { Reduction in ovulation number and severe } \\
\text { failure in fertilization }\end{array}$ & 128 \\
\hline Ptx3 & $\begin{array}{l}\text { Early folliculogenesis factor } \\
\text { regulated by Gdf9 }\end{array}$ & Female, subfertile & Defects in the integrity of the $\mathrm{COC}$ & 54 \\
\hline Smcp & $\begin{array}{l}\text { Enzymatical inactivation of structural } \\
\text { protein in the mitochondrial capsule }\end{array}$ & Male, subfertile & $\begin{array}{l}\text { Reduced sperm motility, migration into } \\
\text { the oviduct and fertilization }\end{array}$ & 129 \\
\hline Spam1 & $\begin{array}{l}\text { Penetration through the cumulus layer } \\
\text { and binding to ZP }\end{array}$ & Male and female, fertile & Delayed COC dispersion & 59 \\
\hline Spag11a & Microbicidal and cytotoxic peptides & Not examined & Reduced sperm motility in knockdown rat & 130 \\
\hline Tnfip6 & $\begin{array}{l}\text { Early folliculogenesis factor } \\
\text { regulated by Gdf9 }\end{array}$ & Female, infertile & Failed COC expansion & 52 \\
\hline Tssk6 & Spermiogenesis and sperm function & Male, infertile & $\begin{array}{l}\text { Abnormal sperm morphology and defects } \\
\text { in sperm-egg fusion through the aberrant } \\
\text { regulation of Izum01 localization }\end{array}$ & 110 \\
\hline Zan & ZP binding & Not examined & Not examined & 131 \\
\hline$Z p 1$ & ZP formation & Female, reduced fertility & Abnormal ZP and defects in fertilization & 86 \\
\hline$Z p 2$ & ZP formation and sperm binding & $\begin{array}{l}\text { Female, severely reduced } \\
\text { fertility }\end{array}$ & $\begin{array}{l}\text { Fragile oocytes with defects } \\
\text { in developmental competence }\end{array}$ & 87 \\
\hline Zp3 & $\begin{array}{l}\text { ZP formation, sperm binding, } \\
\text { and acrosome reaction }\end{array}$ & $\begin{array}{l}\text { Female, severely reduced } \\
\text { fertility }\end{array}$ & Lack of ZP and fragile oocytes & 88 \\
\hline$Z p 3 r$ & ZP binding & Not examined & Not examined & 101 \\
\hline$Z p b p$ & ZP binding & Male, infertile & Asthenoglobozoospermia & 132 \\
\hline
\end{tabular}

Pcsk4, proprotein convertase subtilisin/kexin type 4; Piga, phosphatidylinositol glycan anchor biosynthesis, class A; Pkdrej, polycystic kidney disease (polycystin) and REJ (sperm receptor for egg jelly, sea urchin homolog)-like; Prss21, protease, serine, 21; Ptgs2, prostaglandin-endoperoxide synthase 2; Smcp, sperm mitochondria-associated cysteine-rich protein; Spag11a, sperm-associated antigen 11a; Zp3r, Zp3 receptor (also known as Sp56); Zpbp, ZP-binding protein.

reach the egg in vivo. This control step is bypassed by IVF, which usually requires thousands of sperm to occur successfully.

After leaving the storage reservoir, sperm move into the ampulla and locate the cumulus-cell oocyte complex (COC). The COC is comprised of ovulated eggs covered by the ZP and a multicellular cumulus oophorus. Sperm chemotaxis is implicated in locating the COC. In particular, human sperm have been reported to sense a chemoattractant from both follicular fluid (44) and COCs (45). Progesterone was proven to be the cumulus-derived chemoattractant by the observation that antiprogesterone treatment abrogated the in vitro chemotactic activity of human (46) and rabbit (47) cumulus-cultured medium. Olfactory receptor, family 1 , subfamily D, member 2 (OR1D2) was also demonstrated to function in human sperm chemotaxis and induced calcium signaling when sperm were exposed in vitro to the representative chemical attractant bourgeonal (an aromatic aldehyde) (48). The contribution of these factors to in vivo fertilization awaits analysis by gene-knockout approaches.

\section{Sperm-cumulus interaction}

Soon after interacting with COCs, sperm penetrate the matrix of the cumulus oophorus, which is rich in proteins and carbohydrates such as hyaluronan, an unsulfated glycosaminoglycan (Figure 1). In marsupials, eggs shed their cumulus layers just before ovulation, and the cumulus-free eggs are fertilized in vivo $(49,50)$. Mouse eggs freed from cumulus using hyaluronidase can be fertilized in vitro. However, the cumulus layers surrounding the mouse oocyte are beneficial for fertilization, and genetic deletion of a number of genes involved in synthesizing and stabilizing the COC extracellular matrix suppresses fertilization in vivo. Female mice lacking any one of the factors $\alpha 1$ microglobulin/bikunin (Ambp) (51), TNF- $\alpha$-induced protein 6 (Tnfip6) (52, 53), and pentraxin 3 (Ptx3) (54) have been shown to exhibit reduced female fertility, due to defects in the integrity of the COC. In these female mice, the number of ovulated oocytes in the oviduct was reduced, but the oocytes that reached the oviduct showed impaired fertilizing ability. 

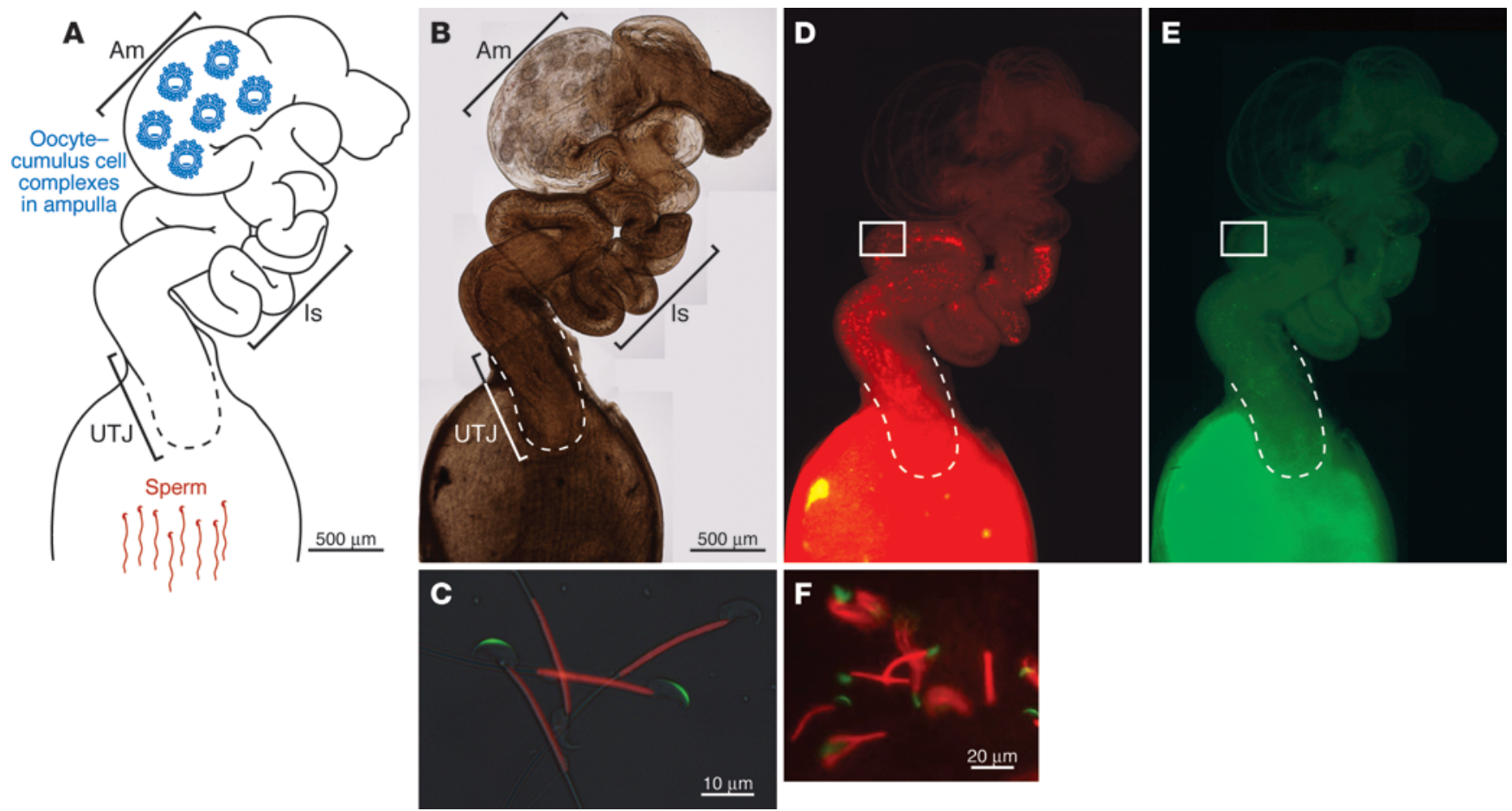

\section{Figure 2}

Sperm migration through the female reproductive tract. After sperm are deposited in the female reproductive environment, they become metabolically active and start migrating into the oviduct. (A and $\mathbf{B}$ ) Depicted here is one oviduct in a female mouse. The generation of sperm engineered to express fluorescent proteins has facilitated visualization of sperm migration through the female reproductive tract $(65,66)$. (C) Sperm from mice engineered to express acrosome-targeted EGFP (acrEGFP) and mitochondria-targeted red fluorescent protein (mtDsRed2). GFP is released during the acrosome reaction, so that acrosome-reacted sperm are no longer acrEGFP+ but remain mtDsRed2+ (66). The mice are available through public bioresource centers. (B and D-F) The female mouse reproductive tract removed at four hours after coitus. The sperm and their acrosomal status can be monitored through the uterine and oviduct wall. Areas indicated in $\mathbf{D}$ and $\mathbf{E}$ are merged in $\mathbf{F}$. The images in $\mathbf{B}$, D, and $\mathbf{E}$ are a composite of several images. Scale bar: $500 \mu \mathrm{m}$ (B, D, and E). Am, ampulla; Is, isthmus.

It was recently reported that cumulus cells secrete CCL chemokines upon activation of the TLR system by hyaluronan fragments generated by sperm hyaluronidase (55). The study of prostaglandin E receptor subtype EP2-knockout (Ptger2-knockout) mice also supports the notion that CCL chemokines facilitate sperm migration to the COC. Ptger2 is expressed in cumulus cells and helps to lower the release of Ccl7. Without Ptger2, release of Ccl7 is increased and prevents fertilization by causing the cumulus extracellular matrix to harden (56). Timely interaction between prostaglandin and chemokine signaling in the cumulus may assist monospermic fertilization.

Sperm adhesion molecule 1 (Spam 1$)$ was first identified as a sperm receptor for the ZP but was later proven to have hyaluronidase activity and was implicated in sperm passage through the COC $(57,58)$. The originally described ZP-binding ability is not physiologically essential, because Spam $1^{-/}$sperm have been shown to bind the ZP. Spam1-disrupted mice are fertile, although the mutant sperm show a reduced ability to disperse cumulus cells in vitro (59). Tadashi Baba and colleagues found that Spam $1^{-\gamma^{-}}$sperm retain approximately $40 \%$ of their hyaluronidase activity and identified hyaluronoglucosaminidase 5 (Hyal5) as an additional spermspecific hyaluronidase (60). When they generated $\mathrm{Hyal5}^{-/}$mice, sperm fertility was comparable to that of wild-type mice, both in vitro and in vivo (61), suggesting a more important role for Spam1 than Hyal5 during sperm passage through the cumulus layers. It will be interesting to determine the details of the sperm fertilizing ability in Spam 1 ${ }^{-/-} \mathrm{Hyal5}^{-/-}$double-knockout mice in the future.

\section{Acrosome reaction}

The acrosome is a Golgi-derived exocytotic organelle that covers the tip of the sperm head (Figure 1). Acrosomal exocytosis, the socalled acrosome reaction, happens only in capacitated sperm and is a prerequisite for a sperm to fuse with an egg (Figure 1). Because of its physiological importance, various methods have been proposed to assess acrosomal status (62-64). Taking advantage of mice engineered to express GFP in the acrosome, we have been able to observe, in real-time, the acrosome reaction in live sperm without any pretreatment (Figure 2$)(65,66)$. It is noteworthy that the acrosome reaction is not a simple all-or-none event but one with intermediate stages. While the soluble GFP disperses from the acrosome within seconds (65), other acrosomal components are only gradually released. For example, the MN7 and MC41 (acrin1 and acrin2) acrosomal antigens remain attached to the sperm head for at least 15 minutes (67). Further investigation of these intermediate stages of fertilization is awaited (68).

The acrosome reaction can be induced in vitro with solubilized $\mathrm{ZP}(69-71)$. However, there is a report showing that the intact ZP is not sufficient to induce acrosomal exocytosis (72). Further, according to Ryuzo Yanagimachi, some mouse sperm passing through cumulus layers are already acrosome reacting and have reacted 
before reaching the $\mathrm{ZP}$ (73). In shrews, the acrosome reaction is induced by cumulus cells but not the ZP (74). Progesterone secreted from human cumulus cells is reported to induce the acrosome reaction (75). Moreover, $20 \%-40 \%$ of capacitated mouse sperm spontaneously undergo the acrosome reaction in an IVF medium, such as TYH (76), without any natural inducer, and those sperm are efficiently able to fertilize in vitro eggs without the cumulus oophorus and ZP. Therefore, a direct sperm-ZP interaction does not seem to be necessary for the acrosome reaction and thus may not be "essential" for fertilization, even in vivo (Figure 1).

The mechanism of the acrosome reaction itself has been well characterized. In brief, transient calcium influx leads to activation of phospholipase C (PLC), and activated PLC generates IP3 and diacylglycerol (DAG) from PIP2. IP3 releases calcium from intracellular stores, and DAG mediates PKC activation and phosphorylation of substrate proteins. These early events promote a subsequent calcium influx via transient receptor potential cation channels (TRPCs), which induces the complete acrosome reaction. Disruption of Plcd4 impairs the in vitro ZP-induced acrosome reaction, while the $\mathrm{A} 23187$ ionophore-induced acrosome reaction occurs normally (71).

There is growing evidence that the soluble NSF attachment protein receptor (SNARE) complex regulates the sperm acrosome reaction. Sperm from hydrocephaly with hop gait (Hyh) mice, which have a spontaneous point mutation in the $\alpha$-SNAP-encoding gene (Napa), exhibit severely impaired fertility (77). The problem was traced to a defect in the ZP-induced acrosome reaction. Mice lacking complexin-I (Cplx1), which associates with the SNARE complex and modulates its function (78), also generate sperm with an impaired ability to undergo progesterone-induced acrosome reactions (79). It should be noted that although $\mathrm{Plcd}_{4-/-}$, Hyh, and Cplx $1^{-/-}$mutant sperm are severely impaired in their ability to undergo ligand-induced acrosome reactions, these sperm are still able to fertilize $56.9 \%, 46.3 \%$, and $47.3 \%$ of eggs, respectively, in vitro. These data support the idea that the ligand-induced acrosome reaction is not essential but assists fertilization.

\section{ZP}

After passing through the cumulus oophorus, sperm encounter the $\mathrm{ZP}$, their last hurdle before meeting the egg (Figure 1). The major components of the $\mathrm{ZP}$ are three glycosylated proteins, $\mathrm{Zp} 1$, $\mathrm{Zp} 2$, and $\mathrm{Zp} 3$. There are various reports indicating that $\mathrm{Zp} 3$ functions as the primary sperm receptor and can induce the acrosome reaction (80-82). During the passage of sperm through the $Z P$, $\mathrm{Zp} 2$ is thought to function as a secondary receptor for acrosomereacted sperm. On fertilized eggs, $\mathrm{Zp} 2$ is converted to $\mathrm{Zp} 2 \mathrm{f}$ by an oocyte secretory enzyme(s) to prevent further sperm binding and fertilizing the egg $(83,84)$. $\mathrm{Zp} 1$ is thought to cross-link $\mathrm{Zp} 2 / \mathrm{Zp} 3$ heterodimers and creates the filamentous structure of the $\mathrm{ZP}(85)$. Interestingly, knockout studies have revealed that eggs can form the $\mathrm{ZP}$ in the absence of either $\mathrm{Zp} 1$ or $\mathrm{Zp} 2$ and that sperm can fertilize these eggs $(86,87)$. However, when $\mathrm{Zp} 3$ was disrupted, the $\mathrm{ZP}$ was not formed $(88,89)$. Although oocytes lacking a ZP or with only a thin $\mathrm{ZP}\left(\mathrm{Zp}^{3^{-/-}}\right.$and $Z p 2^{-/-}$oocytes, respectively) were able to be fertilized with wild-type sperm, their developmental ability was compromised (87). These results indicate that the ZP helps to maintain an appropriate interaction between granulose cells and oocytes during oocyte maturation. ZP4 has been identified in some species, including humans, but its species-specific function(s) remains to be determined (90).
The ZP not only functions as a receptor for sperm but also acts as a species-specific barrier (73). Rankin et al. replaced mouse Zp2 and $\mathrm{Zp} 3$ with their human homologs and examined the fertilization potential of eggs surrounded with a mouse $Z \mathrm{p} 1 /$ human ZP2/human ZP3 chimeric ZP (91). Mouse sperm, but not human sperm, were able to bind to the chimeric $\mathrm{ZP}$ and fertilize the eggs. As $\mathrm{Zp} 3$ is thought to be the primary sperm receptor, these data suggest that oligosaccharides attached to the ZP proteins, rather than the peptide sequences themselves, are critical for speciesspecific sperm binding. This idea is also supported by earlier biochemical studies, showing that enzymatic removal of terminal galactose $(\mathrm{Gal})$ or $\mathrm{N}$-acetylglucosamine $(\mathrm{GlcNac})$ residues from the $\mathrm{ZP}$ abolishes its affinity for sperm (92-94). However, it has been reported that disruption of mannoside acetylglucosaminyltransferase 1 (Mgat1), a medial-Golgi enzyme essential for the synthesis of hybrid and complex $\mathrm{N}$-glycans, resulted in oocytes that were efficiently fertilized, even though the $\mathrm{ZP}$ was fragile and lacked terminal N-glycan Gal and GlcNac residues (95). The same group also disrupted $\mathrm{T}$-synthase (C1galt 1 ) so that $\mathrm{ZP}$ without core 1 and core $2 \mathrm{O}$-glycans was generated. Since there are no core 3 and core $4 \mathrm{O}$-glycans in the ZP, these mice can be considered as having O-glycan-deficient ZP. However, oocytes from these animals were still fertilized by sperm (96). Moreover, oocyte-specific disruption of both Mgat1 and C1galt1 has been achieved, and ZP with no terminal Gal and GlcNac was shown to be functional (96). The results obtained from gene-knockout studies using oocyte-specific Cre recombinase strongly support the idea that the oligosaccharides on the ZP are far less important for sperm-egg interactions than previously believed. An alternative interpretation could be that there are some unknown $\mathrm{ZP}$-associated glycoproteins (derived from ovary or another source where the glycosyl transferases are still expressed) that are important for sperm-egg interactions.

\section{Sperm proteins required for ZP binding}

Various reports exist supporting the notion that B4galt1 on the sperm surface can bind to ZP glycans (97). However, when B4galt1knockout mice were produced, the mutant sperm could fertilize eggs $(9,10)$. The literature is replete with examples of sperm factors that have been demonstrated to be important for ZP binding, using a biochemical approach, but later proven to be not essential in gene-disruption experiments.

Ironically, the first case of normal-looking sperm with defective ZP-binding capacity was generated unexpectedly (15). When sperm from $\mathrm{Clg}^{-/-}$mice were mixed with cumulus-free eggs, the sperm were unable to bind the ZP and were repelled. However, Clgn is not directly involved in sperm-egg interactions, because Clgn is a testis-specific ER molecular chaperone involved in folding newly synthesized secretory and membrane proteins. Even in wild-type male mice, Clgn is absent from mature sperm. We therefore speculated that Clgn facilitates the maturation of a sperm protein(s) required for $\mathrm{ZP}$ binding.

Five knockout mouse strains have now been reported to show defective sperm-ZP binding (Clgn-, Ace-, Adam1a-, Adam2-, and Adam3-knockout mice) (Figure 3). The disruption of Clgn impairs Adam1a/Adam2 and Adam1b/Adam2 heterodimerization, and because these other ADAM family members regulate the amount of Adam 3 on sperm, this leads to the complete loss of Adam2 and Adam 3 from the surface of mature sperm $(23,28)$. When Baba and colleagues produced Adam $1 b$-knockout mice, Adam2 was also found to disappear from sperm, but Adam3 remained 


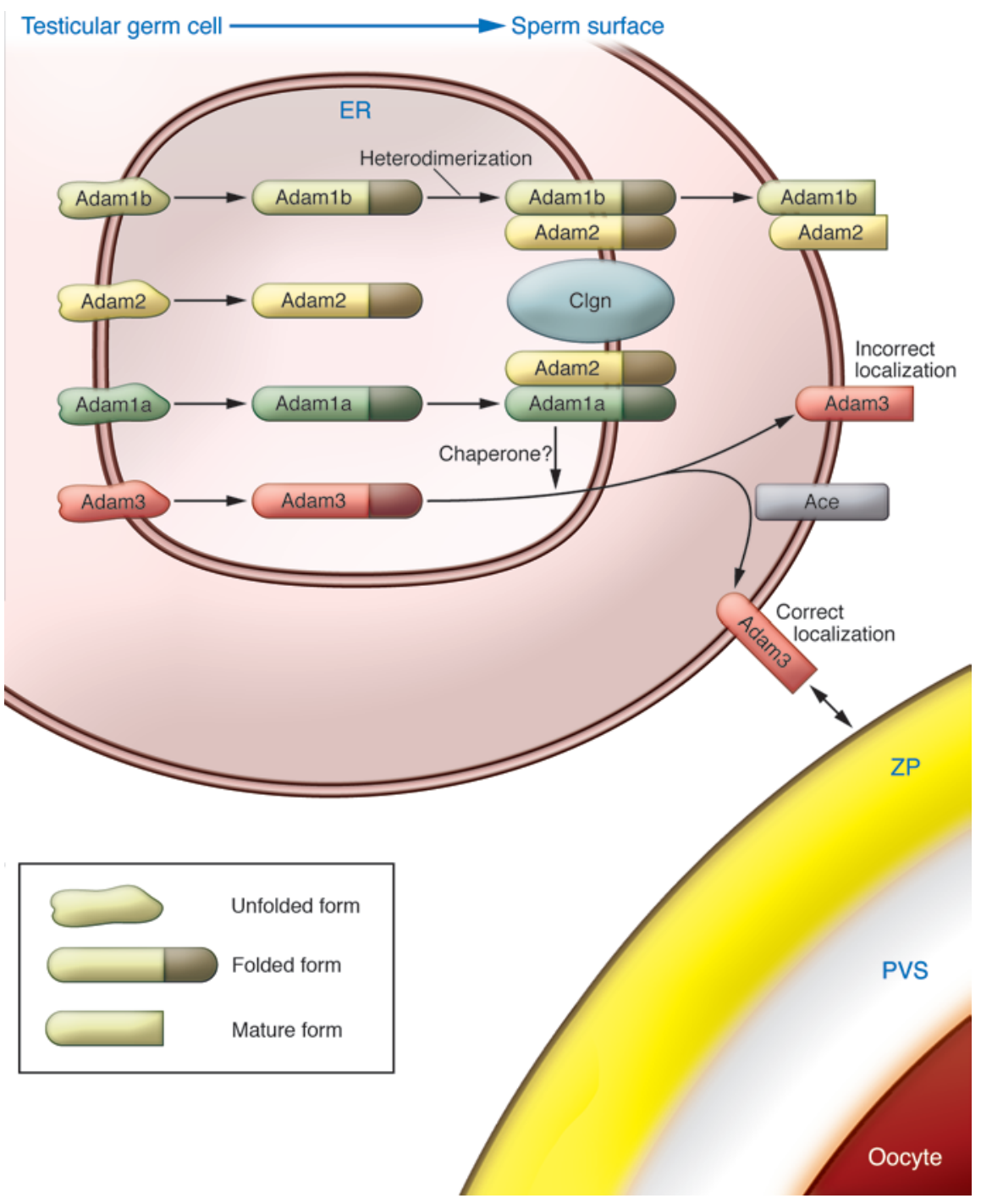

Figure 3

Maturation of ADAMs and their roles in sperm function. Disruption of the genes Clgn, Ace, Adam1a, Adam2, and Adam3 results in impaired sperm-ZP binding and impaired migration through the UTJ. Clgn is required for Adam1a/Adam2 and Adam1b/Adam2 heterodimerization. Lack of Adam1a/Adam2 heterodimerization in $\mathrm{Clgn}^{-1-}, \mathrm{Adam}_{1} \mathrm{a}^{-/-}$, and Adam2-/- mice causes Adam3 disappearance from the surface of mature sperm. Disruption of Ace leads to aberrant localization of Adam3, as evidenced by reduced amounts of Adam3 protein in the Triton $\mathrm{X}-114$ detergentenriched phase of sperm membranes (28). The diagram illustrates why disruption of the individual Ace, Clgn, Adam1a, Adam2, and Adam3 genes produces similar phenotypes and indicates the importance of Adam3 in sperm fertilizing ability. intact and the sperm were fertile (11). When Adam1a, which is ER specific and not found in mature sperm, was knocked out, Adam 2 remained intact, but the sperm lost surface expression of Adam 3 and ZP-binding ability (25). This result clearly indicates that Adam1b/Adam 2 (i.e., fertilin) is dispensable for fertilization, at least in mice. This result is surprising, because there was strong evidence that the disintegrin domain of fertilin on sperm interacted with the RGD domain of integrins on oocytes and that the addition of RGD fragments to sperm inhibited fertilization. One could argue that some other factor(s) compensates for the loss of fertilin in gene-disrupted mice during spermatogenesis, but that the same factor(s) is not able to compensate for the loss of fertilin function when inhibitory antibodies or exogenous ligands are added. However, it could be counter-argued that the fertilization inhibiting activity of the antibody and/or ligands was not physiological but rather an artifactual effect. Since the entire mechanism of fertilization is yet to be clarified, the outcome of the debate awaits further investigations.

The Adam 3 protein can directly bind to the ZP (60). It appears that Adam 3 requires the concerted action of Clgn and Adam 1a/ Adam 2 for its quality control and maturation during spermato- genesis. The mechanism of infertility caused by Ace disruption remained unclear for many years, since overall levels of ADAMs in sperm are not influenced by Ace. Recently, however, we noticed a substantial decrease in the amount of Adam 3 in membrane microdomains and suggested that erroneous distribution of Adam 3 in $\mathrm{Ace}^{-/-}$mice might cause the defective ZP-binding phenotype (28) (Figure 3). These observations point toward Adam3 as the most important factor that participates in sperm-ZP binding. However, in humans, other ADAMs, or another protein, are likely to function as an alternative to Adam3, because the human homolog of Adam3 seems to be a pseudo gene $(98,99)$. In fact, there are various papers showing that other proteins are involved in human sperm binding to the $\mathrm{ZP}$, including the $56-\mathrm{kDa} \mathrm{Zp} 3$ receptor $(\mathrm{ZP} 3 \mathrm{R})$ and zonadhesin $(\mathrm{ZAN}) . \mathrm{Zp} 3 \mathrm{r}$ is a peripheral membrane glycoprotein that has been suggested to be a receptor for $\mathrm{Zp} 3$ in the mouse $(100,101)$, whereas ZAN is a large sperm head protein, with multiple isoforms, that has been implicated in species-specific gamete recognition (102).

In addition to their inability to bind to the ZP, sperm from Clgn-, Ace-, Adam1a-, Adam2-, and Adam3-knockout mice share another notable phenotype: they are unable to migrate into the oviduct 

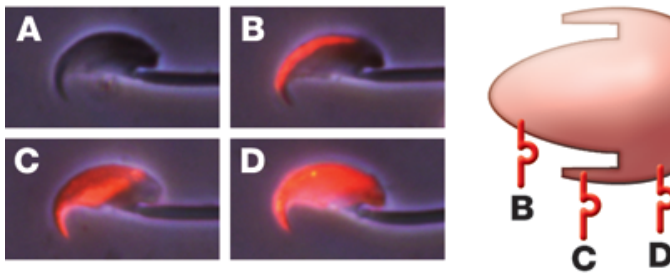

-
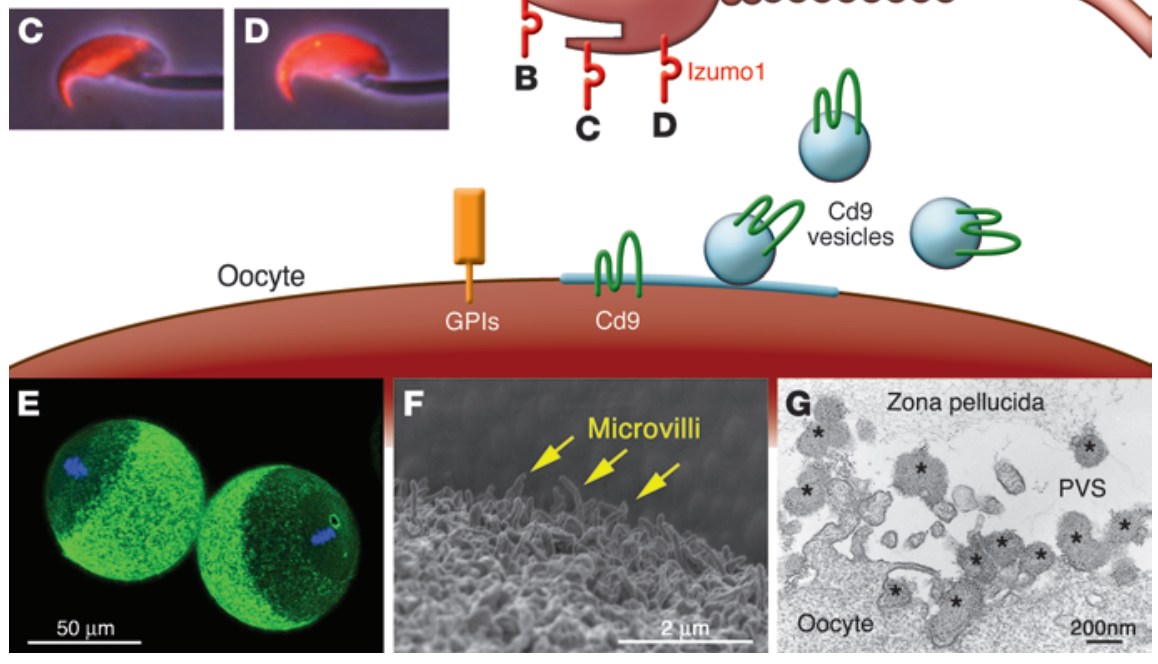

\section{Figure 4}

Potential mechanism of sperm-egg fusion. Sperm Izumo1 and egg Cd9 are essential factors for sperm-egg fusion $(13,16)$. GPIanchored proteins on the egg surface are also essential (114), but none of the individual proteins have been identified. (A) Izumo1 is an acrosomal membrane protein that is not exposed before the acrosome reaction is complete. Acrosome-reacted sperm can be classified into three major groups by their Izumo1 staining pattern: acrosomal cap (B), equatorial (C), and whole head (D). (E and F) Cd9 is localized on the cilia distributed across the surface of unfertilized eggs, except the cilia at the metaphase plate. (G) Cd9-containing vesicles (asterisks) secreted from the oocyte are able to translocate onto the sperm surface and may play a role in sperm-egg fusion. $\mathbf{G}$ is reproduced with permission from Proceedings of the National Academy of Sciences of the United States of America (115).
(23-27). This suggests that oviduct migration and ZP binding might share a common mechanism. This hypothesis is supported by the phenotype of a sixth mutant mouse, the post-GPI attachment to proteins 1-knockout (Pgap1-knockout) mouse. Pgap1 is an ER resident GPI inositol-deacylase that is involved in the maturation of GPI-linked proteins. Few Pgap $1^{-1-}$ mice reach sexual maturity. Those male mice that do reach adulthood have sperm that are normal in number and motility but that cannot ascend the oviduct or bind to the $\mathrm{ZP}$ (103). If the reason underlying this commonly observed dual defect is clarified, it will help us to understand the molecular mechanisms of fertilization in more detail.

\section{ZP penetration}

The enzymatic hypothesis for ZP penetration posits that proteolytic cleavage of ZP proteins by sperm cell-surface proteases clears a path for the incoming sperm (73). The enzyme heralded as the prime candidate for the controlled proteolytic clearance of $\mathrm{ZP}$ proteins was Acr. Acr is an acrosomal enzyme with chymotryptic activity that is released during the acrosome reaction. Despite several papers supporting an important role for Acr in ZP binding and penetration, $A \mathrm{cr}^{-1}$ - sperm can still fertilize eggs, albeit with a slight delay compared with wild-type sperm $(8,104)$. Baba and colleagues found that protease activity persists in the sperm of Acr-knockout mice, suggesting that alternative proteases could be involved in $\mathrm{ZP}$ penetration. Five more testis-specific serine proteases have been identified and named Tesp1-Tesp5 (105). Thus far, only mice lacking Tesp5 (also known as Prss21) have been generated and analyzed (106). Sperm from these mice have a diminished ability to bind to the $\mathrm{ZP}$ and fuse with eggs, but curiously, the phenotype is rescued by treating the sperm with uterine fluids. This observation further demonstrates the complex interplay between male and female factors during the course of fertilization.

\section{Sperm-egg fusion}

After penetration of the ZP, sperm immediately meet and fuse with the egg plasma membrane (Figure 4). Electron microscopic observation has shown that sperm that penetrate the $\mathrm{ZP}$ are acrosome reacted $(107,108)$. The fact that only acrosome-reacted sperm are able to fuse with eggs implies that a sperm fusogen(s) is hidden or latent in fresh sperm and becomes exposed or activated only after the acrosome reaction. Many sperm antigens, such as Mn9, Cd46, and Izumo1, become reactive to antibodies only after the acrosome reaction has been completed. We previously raised a monoclonal antibody, OBF13, that inhibited sperm-egg fusion. The cognate antigen was a good candidate for a fusion factor (109). We identified the antigen as an Ig superfamily, type I membrane protein, with an extracellular Ig domain that contains one putative glycosylation site. The antigen was named "IZUMO" after a Japanese Shinto shrine dedicated to marriage. Izumo1 ${ }^{-/-}$male mice are completely sterile, even though the mutant sperm can penetrate the ZP and contact the egg plasma membrane (13). When the fusion step was bypassed by intracytoplasmic sperm injection into unfertilized eggs, Izumo1 $1^{-/-}$sperm activated eggs, and the fertilized eggs developed to term normally when transferred to the uterus of female mice. Therefore, the Izumo1 protein is essential for sperm-egg fusion (13). During the acrosome reaction, Izumo1 relocates from the anterior head of the sperm to the site(s) in which fusion will take place (Figure 4, A-D). Testis-specific serine kinase 6 (Tssk6) is a male germ cell-specific serine kinase, and sperm from mice lacking Tssk6 have defects in ZP binding and do not redistribute Izumo1 properly $(110,111)$.

What is essential on the egg surface? When fertilin was believed to be the essential sperm factor, $\alpha_{6} \beta_{1}$ integrin on the egg surface was considered a likely candidate binding partner (112). However, gene disruption experiments showed that neither $\alpha_{6}$ integrin nor $\beta_{1}$ integrin were essential (113). Instead, a chance discovery led to the identification of the tetraspanin $\mathrm{Cd} 9$ as an egg cell-surface protein essential for fertility (16-18) (Figure 4). Cd9 is ubiquitously expressed and was expected to function in various cells. However, the Cd9-knockout mouse showed a defect restricted to eggs, in which the protein was found to be essential for sperm-egg fusion. Given that Izumo1 is essential for sperm to bind to eggs and that $\mathrm{Cd} 9$ is essential for eggs to bind to sperm, it is tempting to speculate that they interact with each other to form a fusogenic 
complex. However, we, and others, have not detected any direct interaction between sperm Izumo1 and egg Cd9. If these proteins do indeed interact, it is likely that they both require associating proteins on the sperm and egg cell surface, and the identity of these putative factors is being intensively investigated.

\section{Conclusions}

Experiments using gene-manipulated animals are very powerful tools for judging which factors are essential in fertilization. Of course, if a certain factor is judged as "not essential," it does not necessarily mean the factor does not function at all in vivo. The number of genes that are indispensable for fertilization is growing, and their roles and relationships in sperm-ZP interactions are becoming clearer. Gene-disruption experiments are conducted in many research fields, and the number of genes disrupted is increasing day by day. Thus, genes that affect reproduction will continue to be found, even by researchers in different fields. The analysis of both expected and serendipitous fertility phenotypes is steadily bringing into focus a clear image of sperm-egg interaction mechanisms. We therefore believe that the day that we can portray the sequential events in fertilization is drawing closer

\section{Acknowledgments}

We thank our colleagues and collaborators, Kenji Miyado, Yuhkoh Satouh, and Hidetoshi Hasuwa, and Yuko Muro for preparing figures. This study was partly supported by MEXT of Japan and Japan Society for the Promotion of Science.

Address correspondence to: Masaru Okabe, Research Institute for Microbial Diseases, Osaka University, Yamadaoka 3-1, Suita, Osaka, 565-0871, Japan. Phone: 81.6.6879.8338; Fax: 81.6.6879.8376; E-mail: okabe@gen-info.osaka-u.ac.jp.
1. Chang MC. Fertilizing capacity of spermatozoa deposited into the fallopian tubes. Nature. 1951;168(4277):697-698.

2. Austin CR. Observations on the penetration of the sperm in the mammalian egg. Aust J Sci Res B. 1951;4(4):581-596.

3. Austin CR. The capacitation of the mammalian sperm. Nature. 1952;170(4321):326.

4. Chang MC. Fertilization of rabbit ova in vitro Nature. 1959;184(suppl 7):466-467.

5. Yanagimachi R, Chang MC. Fertilization of hamster eggs in vitro. Nature. 1963;200:281-282.

6. Doetschman T, Maeda N, Smithies O. Targeted mutation of the Hprt gene in mouse embryonic stem cells. Proc Natl Acad Sci US A. 1988;85(22):8583-8587.

7. Mansour SL, Thomas KR, Capecchi MR. Disruption of the proto-oncogene int- 2 in mouse embryoderived stem cells: a general strategy for targeting mutations to non-selectable genes. Nature. 1988;336(6197):348-352.

8. Baba T, Azuma S, Kashiwabara S, Toyoda Y. Sperm from mice carrying a targeted mutation of the acrosin gene can penetrate the oocyte zona pellucida and effect fertilization. J Biol Chem. 1994; 269(50):31845-31849.

9. Lu Q, Shur BD. Sperm from beta 1,4-galactosyltransferase-null mice are refractory to ZP3-induced acrosome reactions and penetrate the zona pellucida poorly. Development. 1997;124(20):4121-4131.

10. Asano $\mathrm{M}$, et al. Growth retardation and early death of beta-1,4-galactosyltransferase knockout mice with augmented proliferation and abnormal differentiation of epithelial cells. EMBO J. 1997;16(8):1850-1857.

11. Kim E, et al. Mouse sperm lacking ADAM1b/ ADAM2 fertilin can fuse with the egg plasma membrane and effect fertilization. J Biol Chem. 2006; 281(9):5634-5639

12. Ren D, et al. A sperm ion channel required for sperm motility and male fertility. Nature. 2001; 413(6856):603-609.

13. Inoue $\mathrm{N}$, Ikawa $\mathrm{M}$, Isotani A, Okabe $\mathrm{M}$. The immunoglobulin superfamily protein Izumo is required for sperm to fuse with eggs. Nature. 2005; 434(7030):234-238

14. Krege JH, et al. Male-female differences in fertility and blood pressure in ACE-deficient mice. Nature. 1995;375(6527):146-148.

15. Ikawa $\mathrm{M}$, et al. The putative chaperone calmegin is required for sperm fertility. Nature. 1997; 387(6633):607-611.

16. Miyado K, et al. Requirement of CD9 on the egg plasma membrane for fertilization. Science. 2000; 287(5451):321-324.

17. Kaji K, et al. The gamete fusion process is defective in eggs of Cd9-deficient mice. Nat Genet. 2000;
24(3):279-282.

18. Le Naour F, Rubinstein E, Jasmin C, Prenant M, Boucheix C. Severely reduced female fertility in CD9deficient mice. Science. 2000;287(5451):319-321.

19. Eliasson R. Cholesterol in human semen. Biochem J. 1966;98(1):242-243.

20. Yano R, et al. Bactericidal/Permeability-Increasing Protein (BPI) is associated with the acrosome region of rodent epididymal spermatozoa [published online ahead of print September 10, 2009]. J Androl. doi:10.2164/jandrol.109.007880.

21 . De Jonge C. Biological basis for human capacitation. Hum Reprod Update. 2005;11(3):205-214.

22. Tollner TL, Yudin AI, Treece CA, Overstreet JW, Cherr GN. Macaque sperm coating protein DEFB126 facilitates sperm penetration of cervical mucus. Hum Reprod. 2008;23(11):2523-2534.

23. Ikawa $\mathrm{M}$, et al. Calmegin is required for fertilin alpha/beta heterodimerization and sperm fertility. Dev Biol. 2001;240(1):254-261.

24. Hagaman JR, et al. Angiotensin-converting enzyme and male fertility. Proc Natl Acad Sci U S A. 1998; 95(5):2552-2557.

25. Nishimura H, Kim E, Nakanishi T, Baba T. Possible function of the ADAM1a/ADAM2 Fertilin complex in the appearance of ADAM3 on the sperm surface. J Biol Chem. 2004;279(33):34957-34962.

26. Cho C, et al. Fertilization defects in sperm from mice lacking fertilin beta. Science. 1998; 281(5384):1857-1859.

27. Yamaguchi R, et al. Disruption of ADAM3 impairs the migration of sperm into oviduct in mouse. Biol Reprod. 2009;81(1):142-146.

28. Yamaguchi R, Yamagata K, Ikawa M, Moss SB, Okabe M. Aberrant distribution of ADAM3 in sperm from both angiotensin-converting enzyme (Ace)- and calmegin (Clgn)-deficient mice. Biol Reprod. 2006;75(5):760-766

29. Shamsadin R, Adham IM, Nayernia K, Heinlein UA, Oberwinkler H, Engel W. Male mice deficient for germ-cell cyritestin are infertile. Biol Reprod. 1999;61(6):1445-1451.

30. Ignotz GG, Cho MY, Suarez SS. Annexins are candidate oviductal receptors for bovine sperm surface proteins and thus may serve to hold bovine sperm in the oviductal reservoir. Biol Reprod. 2007;77(6):906-913.

31. Suarez SS. Regulation of sperm storage and movement in the mammalian oviduct. Int I Dev Biol. 2008;52(5-6):455-462.

32. Lefebvre J, Fan J, Chevalier S, Sullivan R, Carmona E, Manjunath P. Genomic structure and tissue-specific expression of human and mouse genes encoding homologues of the major bovine seminal plasma proteins. Mol Hum Reprod. 2007;13(1):45-53.

33. Gualtieri R, Mollo V, Duma G, Talevi R. Redox control of surface protein sulphhydryls in bovine spermatozoa reversibly modulates sperm adhesion to the oviductal epithelium and capacitation. Reproduction. 2009;138(1):33-43.

34. Dobrinski I, Smith TT, Suarez SS, Ball BA. Membrane contact with oviductal epithelium modulates the intracellular calcium concentration of equine spermatozoa in vitro. Biol Reprod. 1997;56(4):861-869.

35. Murray SC, Smith TT. Sperm interaction with fallopian tube apical membrane enhances sperm motility and delays capacitation. Fertil Steril. 1997; 68(2):351-357.

36. Ignotz GG, Lo MC, Perez CL, Gwathmey TM, Suarez SS. Characterization of a fucose-binding protein from bull sperm and seminal plasma that may be responsible for formation of the oviductal sperm reservoir. Biol Reprod. 2001;64(6):1806-1811.

37. Demott RP, Suarez SS. Hyperactivated sperm progress in the mouse oviduct. Biol Reprod. 1992; 46(5):779-785

38. Ho K, Wolff CA, Suarez SS. CatSper-null mutant spermatozoa are unable to ascend beyond the oviductal reservoir. Reprod Fertil Dev. 2009;21(2):345-350.

39. Carlson AE, et al. CatSper1 required for evoked Ca2+ entry and control of flagellar function in sperm. Proc Natl Acad Sci U S A. 2003;100(25):14864-14868.

40. Qi H, et al. All four CatSper ion channel proteins are required for male fertility and sperm cell hyperactivated motility. Proc Natl Acad Sci U S A. 2007; 104(4):1219-1223.

41. Avenarius MR, et al. Human male infertility caused by mutations in the CATSPER 1 channel protein. Am J Hum Genet. 2009;84(4):505-510.

42. Hunter RH. Ovarian control of very low sperm/ egg ratios at the commencement of mammalian fertilisation to avoid polyspermy. Mol Reprod Dev. 1996;44(3):417-422.

43. Hunter RH, Leglise PC. Polyspermic fertilization following tubal surgery in pigs, with particular reference to the role of the isthmus. J Reprod Fertil. 1971;24(2):233-246.

44. Cohen-Dayag A, Tur-Kaspa I, Dor J, Mashiach S, Eisenbach M. Sperm capacitation in humans is transient and correlates with chemotactic responsiveness to follicular factors. Proc Natl Acad Sci U S A. 1995;92(24):11039-11043.

45. Sun F, et al. Human sperm chemotaxis: both the oocyte and its surrounding cumulus cells secrete sperm chemoattractants. Hum Reprod. 2005;20(3):761-767.

46. Oren-Benaroya R, Orvieto R, Gakamsky A, Pinchasov $\mathrm{M}$, Eisenbach $\mathrm{M}$. The sperm chemoattractant secreted from human cumulus cells is progesterone. Hum Reprod. 2008;23(10):2339-2345.

47. Guidobaldi HA, Teves ME, Unates DR, Anastasia A, Giojalas LC. Progesterone from the cumulus cells is the sperm chemoattractant secreted by the rabbit oocyte cumulus complex. PLoS One. 2008;3(8):e3040. 
48. Spehr M, et al. Identification of a testicular odorant receptor mediating human sperm chemotaxis. Science. 2003;299(5615):2054-2058.

49. Rodger JC, Bedford JM. Separation of sperm pairs and sperm-egg interaction in the opossum, Didelphis virginiana. J Reprod Fertil. 1982;64(1):171-179.

50. Blandau RJ. Biology of eggs and implantation. In: Sex and Internal Secretions. Baltimore, MD: Williams \& Wilkins; 1961;2:797-882.

51. Zhuo L, et al. Defect in SHAP-hyaluronan complex causes severe female infertility. A study by inactivation of the bikunin gene in mice. J Biol Chem. 2001; 276(11):7693-7696.

52. Fulop C, et al. Impaired cumulus mucification and female sterility in tumor necrosis factor-induced protein-6 deficient mice. Development. 2003; 130(10):2253-2261

53. Mukhopadhyay D, Asari A, Rugg MS, Day AJ, Fulop C. Specificity of the tumor necrosis factor-induced protein 6-mediated heavy chain transfer from interalpha-trypsin inhibitor to hyaluronan: implications for the assembly of the cumulus extracellular matrix. J Biol Chem. 2004;279(12):11119-11128.

54. Varani S, et al. Knockout of pentraxin 3, a downstream target of growth differentiation factor- 9 , causes female subfertility. Mol Endocrinol. 2002;16(6):1154-1167.

55. Shimada $M$, et al. Hyaluronan fragments generated by sperm-secreted hyaluronidase stimulate cytokine/chemokine production via the TLR2 and TLR4 pathway in cumulus cells of ovulated COCs, which may enhance fertilization. Development. 2008; 135(11):2001-2011.

56. Tamba S, Yodoi R, Segi-Nishida E, Ichikawa A, Narumiya S, Sugimoto Y. Timely interaction between prostaglandin and chemokine signaling is a prerequisite for successful fertilization. Proc Natl Acad SciU S A. 2008;105(38):14539-14544.

57. Primakoff P, Lathrop W, Woolman L, Cowan A, Myles D. Fully effective contraception in male and female guinea pigs immunized with the sperm protein PH-20. Nature. 1988;335(6190):543-546.

58. Lin Y, Mahan K, Lathrop WF, Myles DG, Primakoff $\mathrm{P}$. A hyaluronidase activity of the sperm plasma membrane protein $\mathrm{PH}-20$ enables sperm to penetrate the cumulus cell layer surrounding the egg. J Cell Biol. 1994;125(5):1157-1163.

59. Baba D, et al. Mouse sperm lacking cell surface hyaluronidase $\mathrm{PH}-20$ can pass through the layer of cumulus cells and fertilize the egg. J Biol Chem. 2002; 277(33):30310-30314.

60. Kim E, Baba D, Kimura M, Yamashita M, Kashiwabara S, Baba T. Identification of a hyaluronidase, Hyal5, involved in penetration of mouse sperm through cumulus mass. Proc Natl Acad Sci U S A. 2005;102(50):18028-18033

61. Kimura M, et al. Functional roles of sperm hyaluronidases, HYAL5 and SPAM1, in fertilization in mice. Biol Reprod. 2009;81(5):939-947

62. Saling PM, Storey BT. Mouse gamete interactions during fertilization in vitro. Chlortetracycline as a fluorescent probe for the mouse sperm acrosome reaction. J Cell Biol. 1979;83(3):544-555.

63. Cross NL, Meizel S. Methods for evaluating the acrosomal status of mammalian sperm. Biol Reprod. 1989;41(4):635-641.

64. Lai YM, et al. Coculture of human spermatozoa with reproductive tract cell monolayers can enhance sperm functions better than coculture with Vero cell monolayers. J Assist Reprod Genet. 1996;13(5):417-422.

65. Nakanishi T, et al. Real-time observation of acrosomal dispersal from mouse sperm using GFP as a marker protein. FEBS Lett. 1999;449(2-3):277-283.

66. Hasuwa H, Muro Y, Ikawa M, Kato N, Tsujimoto Y, Okabe M. Transgenic mouse sperm that have green acrosome and red mitochondria allow visualization of sperm and their acrosome reaction in vivo. Exp Anim. 2010;59(1):105-107.

67. Nakanishi T, Ikawa M, Yamada S, Toshimori K,
Okabe M. Alkalinization of acrosome measured by GFP as a $\mathrm{pH}$ indicator and its relation to sperm capacitation. Dev Biol. 2001;237(1):222-231.

68. Buffone MG, Foster JA, Gerton GL. The role of the acrosomal matrix in fertilization. Int J Dev Biol. 2008;52(5-6):511-522.

69. Cherr GN, Lambert H, Meizel S, Katz DF. In vitro studies of the golden hamster sperm acrosome reaction: completion on the zona pellucida and induction by homologous soluble zonae pellucidae. Dev Biol. 1986;114(1):119-131.

70. Florman HM, Storey BT. Mouse gamete interactions: the zona pellucida is the site of the acrosome reaction leading to fertilization in vitro. Dev Biol. 1982;91(1):121-130.

71. Fukami K, et al. Requirement of phospholipase Cdelta 4 for the zona pellucida-induced acrosome reaction. Science. 2001;292(5518):920-923.

72. Baibakov B, Gauthier L, Talbot P, Rankin TL, Dean J. Sperm binding to the zona pellucida is not sufficient to induce acrosome exocytosis. Development. 2007;134(5):933-943.

73. Yanagimachi R. Mammalian fertilization. In: Knobil E, Neill JD, eds. The Physiology of Reproduction. 2nd ed. New York, NY: Raven Press; 1994:189-317.

74. Bedford JM, Mock OB, Goodman SM. Novelties of conception in insectivorous mammals (Lipotyphla), particularly shrews. Biol Rev Camb Philos Soc. 2004;79(4):891-909.

75. Patrat C, Serres C, Jouannet P. The acrosome reaction in human spermatozoa. Biol Cell. 2000 92(3-4):255-266

76. Toyoda Y, Yokoyama M, Hoshi T. Studies on the fertilization of mouse eggs in vitro I: In vitro fertilization of eggs by fresh epididymal sperm [in Japanese]. Jpn J Anim Reprod. 1971;16:147-151.

77. Batiz LF, et al. Sperm from hyh mice carrying a point mutation in alphaSNAP have a defect in acrosome reaction. PLoS One. 2009;4(3):e4963.

78. Reim K, et al. Complexins regulate a late step in $\mathrm{Ca} 2+-$ dependent neurotransmitter release. Cell. 2001; 104(1):71-81.

79. Zhao L, Burkin HR, Shi X, Li L, Reim K, Miller DJ. Complexin $\mathrm{I}$ is required for mammalian sperm acrosomal exocytosis. Dev Biol. 2007;309(2):236-244.

80. Bleil JD, Wassarman PM. Mammalian sperm-egg interaction: identification of a glycoprotein in mouse egg zonae pellucidae possessing receptor activity for sperm. Cell. 1980;20(3):873-882.

81. Bleil JD, Wassarman PM. Sperm-egg interactions in the mouse: sequence of events and induction of the acrosome reaction by a zona pellucida glycoprotein. Dev Biol. 1983;95(2):317-324.

82. Arnoult C, Zeng Y, Florman HM. ZP3-dependent activation of sperm cation channels regulates acrosomal secretion during mammalian fertilization. J Cell Biol. 1996;134(3):637-645.

83. Bleil JD, Greve JM, Wassarman PM. Identification of a secondary sperm receptor in the mouse egg zona pellucida: role in maintenance of binding of acrosome-reacted sperm to eggs. Dev Biol. 1988; 128(2):376-385.

84. Kurasawa S, Schultz RM, Kopf GS. Egg-induced modifications of the zona pellucida of mouse eggs: effects of microinjected inositol 1,4,5-trisphosphate. Dev Biol. 1989;133(1):295-304.

85. Green DP. Three-dimensional structure of the zona pellucida. Rev Reprod. 1997;2(3):147-156

86. Rankin T, Talbot P, Lee E, Dean J. Abnormal zonae pellucidae in mice lacking ZP1 result in early embryonic loss. Development. 1999;126(17):3847-3855.

87. Rankin TL, O’Brien M, Lee E, Wigglesworth K, Eppig $J$, Dean J. Defective zonae pellucidae in $\mathrm{Zp} 2$-null mice disrupt folliculogenesis, fertility and development. Development. 2001;128(7):1119-1126.

88. Liu C, et al. Targeted disruption of the $\mathrm{mZP} 3$ gene results in production of eggs lacking a zona pellucida and infertility in female mice. Proc Natl Acad
Sci U S A. 1996;93(11):5431-5436.

89. Rankin T, et al. Mice homozygous for an insertional mutation in the $\mathrm{Zp} 3$ gene lack a zona pellucida and are infertile. Development. 1996;122(9):2903-2910.

90. Lefievre L, et al. Four zona pellucida glycoproteins are expressed in the human. Hum Reprod. 2004; 19(7):1580-1586.

91. Rankin TL, et al. Fertility and taxon-specific sperm binding persist after replacement of mouse sperm receptors with human homologs. Dev Cell. 2003; 5(1):33-43

92. Bleil JD, Wassarman PM. Galactose at the nonreducing terminus of O-linked oligosaccharides of mouse egg zona pellucida glycoprotein ZP3 is essential for the glycoprotein's sperm receptor activity. Proc Natl Acad Sci U S A. 1988;85(18):6778-6782.

93. Florman HM, Wassarman PM. O-linked oligosaccharides of mouse egg ZP3 account for its sperm receptor activity. Cell. 1985;41(1):313-324.

94. Shur BD, Hall NG. A role for mouse sperm surface galactosyltransferase in sperm binding to the egg zona pellucida. J Cell Biol. 1982;95(2 Pt 1):574-579.

95. Shi S, et al. Inactivation of the Mgat 1 gene in oocytes impairs oogenesis, but embryos lacking complex and hybrid N-glycans develop and implant. Mol Cell Biol. 2004;24(22):9920-9929.

96. Williams SA, Xia L, Cummings RD, McEver RP, Stanley $\mathrm{P}$. Fertilization in mouse does not require terminal galactose or $\mathrm{N}$-acetylglucosamine on the zona pellucida glycans. J Cell Sci. 2007;120(Pt 8):1341-1349.

97. Lopez LC, Bayna EM, Litoff D, Shaper NL, Shaper $\mathrm{JH}$, Shur BD. Receptor function of mouse sperm surface galactosyltransferase during fertilization. J Cell Biol. 1985;101(4):1501-1510.

98. Hall L, Frayne J. Non-functional fertility genes in humans: contributory factors in reduced male fertility? Hum Fertil (Camb). 1999;2(1):36-41.

99. Grzmil P, et al. Human cyritestin genes (CYRN1 and CYRN2) are non-functional. Biochem J. 2001; 357(Pt 2):551-556.

100. Cheng A, et al. Sperm-egg recognition in the mouse: characterization of $\mathrm{sp} 56$, a sperm protein having specific affinity for ZP3. J Cell Biol. 1994;125(4):867-878.

101. Bookbinder LH, Cheng A, Bleil JD. Tissue- and species-specific expression of sp56, a mouse sperm fertilization protein. Science. 1995;269(5220):86-89.

102. Gao Z, Garbers DL. Species diversity in the structure of zonadhesin, a sperm-specific membrane protein containing multiple cell adhesion molecule-like domains. J Biol Chem. 1998;273(6):3415-3421.

103. Ueda Y, et al. PGAP1 knock-out mice show otocephaly and male infertility. J Biol Chem. 2007; 282(42):30373-30380

104.Adham IM, Nayernia K, Engel W. Spermatozoa lacking acrosin protein show delayed fertilization. Mol Reprod Dev. 1997;46(3):370-376.

105. Honda A, Yamagata K, Sugiura S, Watanabe K, Baba T. A mouse serine protease TESP5 is selectively included into lipid rafts of sperm membrane presumably as a glycosylphosphatidylinositol-anchored protein. J Biol Chem. 2002;277(19):16976-16984.

106.Yamashita M, Honda A, Ogura A, Kashiwabara S, Fukami K, Baba T. Reduced fertility of mouse epididymal sperm lacking Prss $21 /$ Tesp5 is rescued by sperm exposure to uterine microenvironment. Genes Cells. 2008;13(10):1001-1013.

107. Bedford JM. Ultrastructural changes in the sperm head during fertilization in the rabbit. Am J Anat. 1968;123(2):329-358.

108. Stein KK, Primakoff P, Myles D. Sperm-egg fusion: events at the plasma membrane. J Cell Sci. 2004; 117(Pt 26):6269-6274.

109. Okabe M, et al. Capacitation-related changes in antigen distribution on mouse sperm heads and its relation to fertilization rate in vitro. J Reprod Immunol. 1987;11(2):91-100.

110.Sosnik J, et al. Tssk6 is required for Izumo relocalization and gamete fusion in the mouse. J Cell Sci. 2009; 
122(Pt 15):2741-2749.

111.Spiridonov NA, et al. Identification and characterization of SSTK, a serine/threonine protein kinase essential for male fertility. Mol Cell Biol. 2005; 25(10):4250-4261.

112.Almeida EA, et al. Mouse egg integrin alpha 6 beta 1 functions as a sperm receptor. Cell. 1995; 81(7):1095-1104

113. Miller BJ, Georges-Labouesse E, Primakoff P, Myles DG. Normal fertilization occurs with eggs lacking the integrin alpha6beta1 and is CD9-dependent. J Cell Biol. 2000;149(6):1289-1296.

114.Alfieri JA, Martin AD, Takeda J, Kondoh G, Myles DG, Primakoff P. Infertility in female mice with an oocyte-specific knockout of GPI-anchored proteins. J Cell Sci. 2003;116(Pt 11):2149-2155.

115. Miyado K, et al. The fusing ability of sperm is bestowed by CD9-containing vesicles released from eggs in mice. Proc Natl Acad Sci U S A. 2008; 105(35):12921-12926.

116.Yamagata K, et al. Acrosin accelerates the dispersal of sperm acrosomal proteins during acrosome reaction. J Biol Chem. 1998;273(17):10470-10474.

117. Yan C, et al. Synergistic roles of bone morphogenetic protein 15 and growth differentiation factor 9 in ovarian function. Mol Endocrinol. 2001;15(6):854-866.

118. Inoue $\mathrm{N}$, et al. Disruption of mouse CD46 causes an accelerated spontaneous acrosome reaction in sperm. Mol Cell Biol. 2003;23(7):2614-2622.

119. Rubinstein E, et al. Reduced fertility of female mice lacking CD81. Dev Biol. 2006;290(2):351-358.

120.Da Ros VG, et al. Impaired sperm fertilizing ability in mice lacking Cysteine-RIch Secretory Protein 1 (CRISP1). Dev Biol. 2008;320(1):12-18.

121. Kohn MJ, Sztein J, Yagi R, Depamphilis ML, Kaneko KJ. The acrosomal protein Dickkopf-like 1 (DKKL1) facilitates sperm penetration of the zona pellucida [published online ahead of print July 9, 2009]. Fertil Steril. doi:10.1016/j.fertnstert.2009.06.010.

122.Dong J, Albertini DF, Nishimori K, Kumar TR, Lu N, Matzuk MM. Growth differentiation factor-9 is required during early ovarian folliculogenesis. Nature. 1996;383(6600):531-535.

123. Hellsten E, Evans JP, Bernard DJ, Janne PA, Nussbaum RL. Disrupted sperm function and fertilin beta processing in mice deficient in the inositol polyphosphate 5-phosphatase Inpp5b. Dev Biol. 2001; 240(2):641-653.

124. Ensslin MA, Shur BD. Identification of mouse sperm SED1, a bimotif EGF repeat and discoidindomain protein involved in sperm-egg binding. Cell. 2003;114(4):405-417.

125.Gyamera-Acheampong C, et al. Sperm from mice genetically deficient for the PCSK4 proteinase exhibit accelerated capacitation, precocious acrosome reaction, reduced binding to egg zona pelluci- da, and impaired fertilizing ability. Biol Reprod. 2006; 74(4):666-673.

126.Sutton KA, Jungnickel MK, Florman HM. A polycystin-1 controls postcopulatory reproductive selection in mice. Proc Natl Acad Sci U S A. 2008; 105(25):8661-8666.

127. Hizaki $\mathrm{H}$, et al. Abortive expansion of the cumulus and impaired fertility in mice lacking the prostaglandin E receptor subtype $\mathrm{EP}(2)$. Proc Natl Acad Sci US A. 1999;96(18):10501-10506.

128. Lim H, et al. Multiple female reproductive failures in cyclooxygenase 2-deficient mice. Cell. 1997; 91(2):197-208.

129. Nayernia K, et al. Asthenozoospermia in mice with targeted deletion of the sperm mitochondrionassociated cysteine-rich protein (Smcp) gene. Mol Cell Biol. 2002;22(9):3046-3052.

130.Zhou CX, et al. An epididymis-specific beta-defen$\sin$ is important for the initiation of sperm maturation. Nat Cell Biol. 2004;6(5):458-464.

131. Hardy DM, Garbers DL. A sperm membrane protein that binds in a species-specific manner to the egg extracellular matrix is homologous to von Willebrand factor. J Biol Chem. 1995;270(44):26025-26028.

132. Lin YN, Roy A, Yan W, Burns KH, Matzuk MM. Loss of zona pellucida binding proteins in the acrosomal matrix disrupts acrosome biogenesis and sperm morphogenesis. Mol Cell Biol. 2007;27(19):6794-6805. 